\title{
Research on Education in Higher Vocational College Collaborating with Open-door to the Outside World
}

\author{
Lanlan He \\ Liaoning Jianzhu Vocational College, Liaoyang, China \\ helanlan111000@163.com
}

\begin{abstract}
Keywords: Higher Vocational College; Open-door to the Outside World; International Cooperation; Working Mechanism
\end{abstract}

\begin{abstract}
According to the theory and practice of education in higher vocational college, the process of teaching collaborating with open-door to the outside world is not enough in modern teaching evaluation. The results oriented collaborative innovation theory put forward the reform of the development goal. After the reform, the education in higher vocational college collaborating with open-door to the outside world is more suitable for the concept of international education. This paper elaborate the orientation of the international work of colleges and universities under the new situation and proposed the measures to strengthen international cooperation and exchange capacity.
\end{abstract}

\section{Introduction}

Under the background of global integration, the trend of internationalization of higher vocational education is increasingly obvious, and its forms of expression are increasingly diversified [1]. For a country, the opening up of education is an important way to enhance national soft power and international influence [2]. With the increase of China's opening to the outside world and the improvement of its international status, the degree of opening up of higher education in China is also increasing. This is of great significance for guiding all departments to carry out foreign affairs from a higher level.

As an indispensable part of the opening to the outside world, colleges and universities should further clarify the position of international cooperation and exchange under the guidance of the top level design, strengthen the thinking and practice of international development and planning, and better serve the work of the center. In the trend of higher education internationalization, the exchange among universities in the world has become more frequent. Internationalization has become the basic feature of the world's first-class universities. Many universities around the world jointly carry out international cooperation projects in order to promote their own development [3]. In recent years, because of the rapid development of China's economy and playing an increasingly important role on the international stage, many foreign universities have listed China as an important object of cooperation in the international development strategy or measures [4]. Universities in China are faced with important development opportunities in the tide of internationalization of higher education.

At this stage, the internationalization of colleges and universities is no longer a simple transaction oriented reception, but rather a diversified, pragmatic and longitudinal development. International exchanges have preliminarily formed a comprehensive, multi-level and wide field of opening to the outside world. The students' international training projects and the number of dispatched people have been increasing. The construction and cultivation of some international scientific and technological cooperation platforms is built, and the steady growth of the students and the continuous optimization of the structure of the students is obvious. Internationalization has become the idea of running schools and the strategy of managing schools in many universities in China. It is an important way to build a first-class and internationally renowned research university in China. It is a strong support for cultivating high quality and innovative talents with innovative consciousness and international vision. 


\section{Diversification Model}

The teaching method is diversified and the classification vector is

$A_{j}=\sum_{i=1}^{n} q_{1} \cdot a_{i j} \quad j=1, \ldots, m$

The diversity index of teaching method is

$$
I_{R j}=\frac{A_{j}}{\sum_{j=1}^{m} A_{j}}=\frac{A_{j}}{\sum_{i=1}^{m}\left(\sum_{i=1}^{n} q_{1} a_{1 i}\right)}
$$

The concentration of teaching methods is

$$
H_{R}=\sum_{j=1}^{m} I_{R j}^{2}
$$

Diversification index of learning effect

$$
I_{M j}=\frac{S_{j}}{\sum_{j=1}^{m} s_{j}}
$$

The concentration of learning effect is

$$
H_{M}=\sum_{j=1}^{m} I_{M j}^{2}
$$

The comprehensive ability diversification index is

$$
I_{R M j}=\frac{I_{R j} I_{M j}}{\sum_{i=1}^{m} I_{R i} I_{M i}}
$$

The concentration degree of comprehensive diversification is

$$
H_{R M}=\sqrt{\sum_{j=1}^{m} I_{R M j}^{2}}
$$

\section{The Orientation of the International Work of Colleges and Universities under the New Situation.}

Serve the Work of the State. Colleges and universities are one of the important carriers of education opening to the outside world. Under the new situation, the development of international exchanges and cooperation between colleges and universities can not be separated from the overall opening up of the country. The opening of education has entered a new stage, and it also puts forward higher requirements for the international exchange and cooperation of colleges and universities, and the international work should serve the development of the country actively. In specific implementation, colleges and universities should make use of their own academic resources to play their unique advantages and support functions, such as talent training, service industry and so on, and actively integrate and serve the national development strategy.

Serve the central work of the school. The international exchange and cooperation of universities should serve the cultivation and scientific research of university personnel. Social services and other core functions and central tasks. Under the background of knowledge economy and globalization, internationalization is an important way for universities to improve their running level and competitiveness. The university should absorb and integrate the international superior resources, use the advanced international teaching ideas and management methods, combine with their own actual conditions, promote the ability and level of the training, scientific research, the construction of the 
teachers team, the construction of the management mechanism and so on, and build the internationally famous high level research type. The target service of the University. In addition, in the process of international exchange and cooperation, we should pay attention to the transmission of characteristic education, lead the construction of international cooperation ability, strengthen propaganda and enhance the influence of school overseas.

Serve the International Development of Teachers and Students. Teachers and students are the main body of international communication. The international construction of the school should be people-oriented, take the development of teachers and students as the guidance, innovate the cooperation model, implement all kinds of international cooperation projects, build an exchange platform for teachers and students, make the teachers and students through international exchanges, improve their long-term development ability of teaching, learning and research, and become the participants and beneficiaries of the international construction of the school. At the same time, we should establish and improve the system of guarantee mechanism, provide perfect service and management for the practice of international communication between teachers and students, fully mobilize the enthusiasm of teachers and students, which will help to promote the extensive, deep and continuous development of the international work.

\section{Measures to Strengthen International Cooperation and Exchange Capacity}

Improving the Overall Planning Ability of Foreign Affairs. With the continuous expansion of foreign exchange, higher vocational education in China is in the background of international development, and the degree of opening to the outside world is deepening, and the exchange activities of colleges and universities are becoming more and more frequent. In the future work, colleges and universities should change passivity into initiative in the foreign affairs pattern and background, actively strengthen overall design and pragmatic innovation, open up a new situation of international cooperation and exchange, and expand space for the ability of foreign cooperation in the field of education.

As an integrated service and Management Department of international cooperation and exchange in Colleges and universities, the foreign affairs department should work closely around the center of the school under the guidance of the policy of opening to the outside world, and shift the focus of work to the integration of resources, planning, unified coordination, supervision and management. The overall development strategy and measures are established from the aspects of international consciousness concept, target stratification, implementation approach and guarantee mechanism, so as to integrate international cooperation and exchange work and promote the improvement of school teaching, scientific research, service and management level through substantive international cooperation projects.

The Construction of the Working Mechanism. The international construction of the school is a three-dimensional project. The practical activities of international cooperation and exchange are not only outside the Ministry of foreign affairs, but also to the colleges and other functional units. The college is the main body of teaching and scientific research, and the teachers and students are the real power to carry out international exchanges and cooperation in foreign affairs. At the same time, the in-depth and sustainable development of international cooperation and communication in colleges and universities can not be separated from many departments.

Therefore, in order to mobilize the enthusiasm of all parties and improve the operational efficiency of foreign affairs, it is necessary to establish a multi-level mechanism for promoting international work. The working mechanism is to build up a wide range of platforms at the level of the school level, carry out multi-channel and multi-level cooperation, improve and perfect the system guarantee system, and provide the necessary support and support for the subjects involved in international exchange activities. The faculties and departments build a characteristic international based on its own subject and professional characteristics.

The various functional departments give full play to their own business advantages and integrate the international indicators and services into their own management categories, such as the personnel department, which integrates the international exchange activities of teachers into the assessment of the 
workload. The educational departments have approved the conversion of the credits received by the students in the international exchange, and the logistics department provides external experts. The majority of teachers and students actively participate, make full use of various international cooperation and exchange platform, put themselves in the tide of internationalization, and benefit from the practice of international exchange and improve their academic ability.

Build a Hard and International Team of Foreign Affairs. High level foreign affairs team is the human resource base for the smooth development of the internationalization of schools. To some extent, the foreign affairs work in universities is also an extension of the national diplomatic work. It is a political and policy intensive work.

Foreign affairs personnel must have a firm political belief and a high sense of political responsibility, and resolutely safeguard the interests of the state and the collective. The foreign affairs situation has the characteristics of dynamic change and many influential factors. Therefore, on the basis of familiarity with its own business, foreign affairs personnel should strengthen the attention and study of the hot spots of current affairs and the relevant foreign policy and strategies, improve their political acuity and business ability, and constantly improve the level of foreign affairs. It is necessary to strengthen the construction of service oriented institutions, to strengthen the service consciousness and ability of foreign affairs personnel through regular seminars and lectures on international understanding, and to carry out the specific work.

We should explore and improve the methods of foreign affairs, and provide more convenient and accurate information and service for teachers and students through regular routine meetings, college site office and simplification of business processes. Foreign affairs personnel are encouraged to make full use of the advantages of linking up with overseas universities to learn advanced management concepts and methods in foreign first-class universities.

We should strengthen the information construction of foreign affairs, construct a comprehensive foreign affairs service and management information platform, and improve the working efficiency by using new media propaganda methods and means. Through these ways, we can build up a strong foreign affairs team with strong politics, good business and high efficiency.

\section{Summary}

In a word, in the new era of education opening to the outside world, the international cooperation and exchange of colleges and universities should be in the direction of the situation. On the premise of serving the overall work of the country, serving the work of the school center and serving the development of teachers and students, we should constantly strengthen their own ability and build an effective international exchange pattern.

\section{References}

[1] A. Ravenscroft, A. Schmidt, J. Cook, and C. Bradley. Designing Social Media for Informal Learning and Knowledge Maturing in the Digital Workplace, Journal of Computer Assisted Learning, 28 (2012), 112-120.

[2] JY Nancy, NH Khanna, and K Arputharaj. A Q-back propagated time delay neural network for diagnosing severity of gait disturbances in Parkinson's disease, Journal of Biomedical Informatics, 60 (2016), 169-176.

[3] BBC Onwuagboke, and TKR Singh. Effects of Computer Self-Efficacy on Pre-Service Art Teachers' Achievement in Graphic Design, Pertanika Journal of Social Science \& Humanities, 24 (2016), 1315-1333.

[4] BR Webb, and SB Gallagher. Mapping Commonalities and Differences in Software Engineering and Graphic Design Approaches to Multimedia Systems Development, Journal of Computer Information Systems, 46 (2016), 87-98.

[5] Peng L, Fang W. Heterogeneity of Inferring Reputation of Cooperative Behaviors for the Prisoners' Dilemma Game [J]. Physica A: Statistical Mechanics and its Applications, 2015, 433: 367-378. 